April 2011

\title{
Reflections on the Mass Atrocity Response Operations Project
}

Alex Alvarez

Follow this and additional works at: https://digitalcommons.usf.edu/gsp

\section{Recommended Citation}

Alvarez, Alex (2011) "Reflections on the Mass Atrocity Response Operations Project," Genocide Studies and Prevention: An International Journal: Vol. 6: Iss. 1: Article 10.

Available at: https://digitalcommons.usf.edu/gsp/vol6/iss1/10

This Articles is brought to you for free and open access by the Open Access Journals at Digital Commons @ University of South Florida. It has been accepted for inclusion in Genocide Studies and Prevention: An International Journal by an authorized editor of Digital Commons @ University of South Florida. For more information, please contact digitalcommons@usf.edu. 


\title{
Reflections on the Mass Atrocity Response Operations Project
}

\author{
Alex Alvarez \\ Department of Criminology and Criminal Justice, \\ Northern Arizona University
}

As we become evermore aware of the costs and consequences of genocide and various other human rights abuses, the recognition of the need for more effective prevention and intervention strategies also becomes evermore clear. All too often when outbreaks of violence have occurred, the international community has appeared powerless to prevent it and absolutely ineffective when taking steps to stop the violence and the killing. Perhaps the worst contemporary example of this impotence comes from the Democratic Republic of the Congo. Rooted in the destabilizing effects of the 1994 genocide in neighboring Rwanda, the Eastern Congo has been the setting for mass rapes, massacres, and other atrocities since 1995 as various factions and groups have struggled for power and/or resources or have capitalized on the chaos and brutality. Some estimates suggest that more than 5 million people have been killed since the outbreak of hostilities in the mid-1990s. ${ }^{1}$ This has been the reality there, even though the Congo is the site of one of the longest-standing and largest United Nations peacekeeping missions in existence. Begun in 1999, the United Nations Organization Mission in the Democratic Republic of the Congo (MONUC, renamed MONUSCO in April 2010) has gone from a contingent of about 5,000 troops and 500 military observers to over 20,0000 troops, 700 military observers, 1,000 police personnel, and several thousand assorted other civilian personnel in early $2010 .{ }^{2}$ Despite this significant international presence, the violence has continued to the present day. In fact, some of the more recent mass rapes and massacres have occurred in close proximity to contingents of the UN peacekeeping forces, which have been unwilling or unable to intervene in these atrocities. ${ }^{3}$ Keep in mind that these are not always hit-and-run attacks that occur too quickly for a peacekeeping response. In some cases, the assaults lasted for days. Clearly, MONUSCO has not been very effective in preventing the victimization of innocents. Unfortunately, this has often been more the norm than the exception in locations across the globe. The United Nations and the International Community have usually been unable to prevent and unsuccessful in intervening to stop atrocities.

Because of this apparent lack of prophylactic ability, we have seen the creation of a number of reports, such as the Report of the International Commission on Intervention and State Sovereignty, better known as Responsibility to Protect or R2P 4 and the Albright-Cohen Report, Preventing Genocide. ${ }^{5}$ The purpose of these documents has been to chart a path forward so that the all too frequent mistakes of the past will not be repeated. Both have been produced with a tremendous amount of fanfare and high expectations for their implementation, although their impact to date has been negligible and their long-term prospects unclear. Nevertheless, these well-intentioned projects have been important first steps in conceptualizing and

Alex Alvarez, "Reflections on the Mass Atrocity Response Operations Project," Genocide Studies and Prevention 6, 1 (April 2011): 70-76. (C) 2011 Genocide Studies and Prevention. doi:10.3138/gsp.6.1.70 
institutionalizing strategies to prevent genocide and related forms of human rights violations and will hopefully help create and spur further action. To this list, we can now add MARO: Mass Atrocity Response Operations; A Military Planning Handbook, which seeks to outline how military interventions to save civilian lives should take place. Comprehensive and thorough, $M A R O$ is intended to provide a framework to assist the military in visualizing the relevant issues and assessing the specific difficulties inherent in military interventions to prevent atrocities. The handbook is also intended to guide the planning and implementation of such a response. This is certainly no abstract theoretical exercise since it utilizes the insights and experiences of a good number of active duty and retired military personnel. MARO, in short, is grounded in the expertise derived from real world operations and exercises. Therein lies the greatest strength of this project but also, however, what I perceive to be a significant weakness.

The first issue that I have with this handbook concerns some fundamental assumptions that are made by the architects of this plan and has nothing to do with its content. For me, this first issue has more to do with the way we approach or frame the topic rather than the actual strategies suggested or the ways in which they should be implemented. Essentially, this handbook provides a planning guide for military intervention. While I absolutely understand that military intervention is sometimes necessary and that operational plans are crucial for any military intending to act effectively in order to put an end to atrocities, I question our constant willingness to privilege military options over other strategies of intervention. This handbook continues that focus. If this were simply another internal military operations guide or field manual-one of the many that presumably exist-that would be one thing, but the widespread dissemination of this handbook and its attendant publicity suggest otherwise. Essentially, MARO explicitly asserts its purpose as such:

\begin{abstract}
$[M A R O]$ seeks to enable the United States and the international community to stop genocide and mass atrocity as part of a broader integrated strategy by explaining key relevant military concepts and planning considerations. The MARO Project is based on the insight that the failure to act in the face of mass killings of civilians is not simply a function of political will or legal authority; the failure also reflects a lack of thinking about how military forces might respond. ${ }^{6}$
\end{abstract}

This ambitious goal suggests that the MARO Handbook is intended to be or envisions itself as an important component of US strategy when dealing with human rights abuses. In some ways, MARO is analogous to FM 3-24, the US Army's field manual for conducting counterinsurgency operations, which was arguably not intended solely for a military audience. ${ }^{7}$ Its widespread release for download and the fact that it was printed as a book suggest that the public and political audience were important constituencies whose support of the COIN (i.e., counterinsurgency) doctrine it outlines was necessary. At that time, public support for the war in Iraq was in deep decline and the marketing of the strategies outlined in FM 3-24, often referred to as "the troop surge" or simply "the surge," helped garner enough popular and political support for it to be implemented. ${ }^{8}$ The presentation of this document suggests a comparable vision and/or approach.

This focus on military intervention is somewhat problematic since it helps to frame and shape the nature of the discourse about options and policies in ways that reflect an increasing orientation towards military solutions for international problems. I do understand that the primary author of the handbook, Sarah Sewall, developed 
this initiative after having spent time in the Pentagon, that her experience there has been fundamental in shaping the nature of this project, and that the numerous military participants in this project were invaluable in creating a realistic document; yet, it seems to me that, as a society, we already emphasize military options and responses over diplomatic, legal, humanitarian, economic, and informational ones. In his recent critique of our national security mindset, Andrew Bacevich points out that since the Second World War our statecraft has "emphasized activism over example, hard power over soft, and coercion (often styled 'negotiating from a position of strength') over suasion."9 This focus, however, comes at a cost. We tend to perceive non-military options as too slow or too ineffective and often discount them in favor of armed intervention strategies. We want quick solutions to difficult issues and military options often appear to provide that. Yet we live in an increasingly interconnected world in which international economic and social relations have a power and relevancy all too frequently ignored by political and military strategists who continue to perceive the world through old paradigms. This handbook, while filling a gap in the military's preparedness for humanitarian intervention, also serves to perpetuate a mentality in which force remains a pre-eminent tool of intervention. That is not to suggest that military interventions are already the most common international tool. Far from it. But the frequency with which the United States has engaged in military actions around the globe has increased to the extent that this country exists, to borrow Bacevich's term, in a "condition approximating perpetual war." 10 If recent history is any guide, the United States is increasingly relying upon its military forces to project American power abroad and to intervene in a variety of settings for numerous causes. From Lebanon, Grenada, Kosovo, Bosnia, and Somalia to Yemen, Haiti, Liberia, Columbia, the Philippines, Iraq, and Afghanistan, it seems that the United States frequently relies on military intervention for a variety of causes.

To be fair, MARO does explicitly assert that "Military FDO's will be more effective when combined with diplomatic, informational, and economic actions" (69). Yet the diplomatic measures, informational deterrent options, and economic deterrent options discussed in this handbook are conceived as ways to prove support for military operations, not the other way around. This is an extremely important point since it suggests that the military options should enjoy supremacy over other nonforce based options. Is this appropriate? Should force and military intervention be the default options for US strategy, even when other tools are available? Or should military intervention be the fallback when other strategies fail? Given the hazards and enormous costs of military intervention, economically but especially in terms of human life and suffering, should we really be suggesting, either overtly or through implication, that military intervention to curtail human rights abuses be our favored approach? Although many non-military options, such as diplomacy and sanctions for example, may take time to implement and come to fruition, it is equally true that these alternatives can be quite effective and that a greater reliance on these kinds of alternatives also demands a more proactive approach to dealing with atrocity situations than we have often adopted. A great deal of work has been done in recent years on developing effective tools for identifying precursors and warning signs for genocidal atrocities and many NGO's have become quite effective in calling attention to developing situations in countries around the world. ${ }^{11}$ These alternatives, however, are typically not given the same weight as military solutions even though they have the potential to prevent atrocities before violence ever breaks out. Military intervention, on the other hand, is by definition reactive rather than proactive. The 
killing has already begun. Diplomatic, economic, informational, and other such means dictate through necessity an earlier and more preventative approach. Additionally, military interventions are absolutely fraught with a multitude of dangers that can include an escalation of the conflict and the killing of civilians. The NATO intervention in Kosovo, for example, initially served to accelerate the pace at which the Serbs were targeting and killing Kosovar Albanians. When Slobodan Milošević, the president of Serbia, began attacking Albanian separatists in Kosovo in 1998, the international community began applying pressure for him to cease to no avail. Tired of the delaying tactics used by Russia and China in the United Nations Security Council, the United States and its' NATO allies began a bombing campaign against Serb forces in Kosovo and in Serbia itself that, apart from its questionable legality, initially created more refugees and internally displaced persons and increased the intensity and scale of the killings by Serb forces. ${ }^{12}$ Clearly, this was not the intended outcome of this military intervention and, while it was ultimately successful, it took over two months to achieve an end to the hostilities and, as noted above, increased the numbers of civilian victims. American political leaders and NATO officials, anxious to prove the relevance of NATO in a post-Cold War world, had not envisioned the extent of Serbia's resolve and its willingness to endure sustained air attacks. In fact, the top military commander of NATO, General Wesley Clark, had initially expected the mere threat of force to bring an end to the violence in Kosovo. ${ }^{13}$ This kind of difficulty is compounded in atrocity situations, which are notoriously difficult and unpredictable. Atrocities tend to happen during times of other conflicts such as civil wars or low intensity or insurgency wars. In these conflict zones, combatant groups are sometimes indistinguishable from civilian populations or groups from both sides of a conflict engage in war crimes and atrocities. In this confusing and dangerous context, the possibility of civilian casualties, or "collateral damage" as they are sometimes euphemistically called, becomes very real and serves to negate the gains from military intervention for humanitarian reasons. As MARO acknowledges in the section titled "Moral Dilemmas," "In a MARO, the difference between doing right and wrong will be strategically crystalline and tactically elusive. Moral dilemmas will proliferate" (38). Clearly, military intervention is not necessarily an easily implemented panacea and while the handbook acknowledges this in the section titled "Escalatory Dynamics," I am not sure that the underlying implications of this reality are fully addressed.

Military interventions truly must be a tool of last resort. This particular critique does not dispute or challenge the essential strengths of the MARO Handbook; rather it questions the underlying assumptions implicit within its development and dissemination. My criticism is really about the frames of reference or the starting points we use in order to understand and resolve a problem. MARO, unfortunately, replicates our over-reliance on military solutions to international human rights violations. My argument, therefore, does not truly address the validity of the specific suggestions contained in the handbook, but instead argues that we, as a society and as individuals and groups interested in making the world a safer place for civilians, need to emphasize more proactive and non-military approaches to resolving conflicts and trouble spots before they ever erupt into atrocities.

My second major critique is closely connected with the first and also concerns the narrow focus of the handbook. Essentially, the project treats military intervention as a purely military issue without much regard for the political or social aspects of any intervention or, as the authors put it, their purpose is to, "answer the 'how,' not the 'whether'" (13). Yet to ignore the political dimensions of intervention, even military 
interventions, is to suggest that they occur in a vacuum. While $M A R O$ does not completely ignore the political realities of intervention, it does appear to suggest that they are only ancillary to the organization and philosophy of this handbook. The political sphere should be integral in the planning and development of such a handbook. All too often military operations have been hampered and negatively affected by a divergence and lack of cohesion between military goals and political ones. I wonder if it would not have ultimately been more productive to have included political actors in the creation process of $M A R O$ in order to integrate effective strategies designed for better coordination and communication between the military leaders responsible for humanitarian missions and the administration and political leadership who must contend with popular opinion, international pressure, and various other governmental and diplomatic concerns. While it is suggested that the MARO Handbook provides an operationalization of the R2P document, this does not substitute for the need to develop and embed mechanisms to address the political realities of intervention within the MARO project. Additionally, R2P addresses three main areas of responsibility that include the prevention of atrocities, reacting to mass atrocities, and rebuilding after mass atrocities; $M A R O$, therefore, only addresses one of the three main goals of R2P.

Military operations are always constrained, shaped, altered, and retasked according to the variable winds of the political situation and the more that a project such as $M A R O$ can integrate clear guidelines and procedures for working with and within political structures, the more effective such a project will ultimately prove. To suggest that the political sphere is ancillary or irrelevant to the military is to ignore certain realities. A good case in point is the American intervention in Somalia in 1992. Initially tasked with saving lives, Operation Restore Hope was created with the intent to use American troops to create a more secure environment in which humanitarian aid could alleviate the suffering of the Somali people by bringing in food and other vital supplies to the starving population. ${ }^{14}$ While President Bush overtly initiated this mission in response to humanitarian concerns, some have suggested that it was also implemented partially to divert attention away from the then ongoing situation in Bosnia and/or in response to being a lame-duck president in need of a grand gesture. Regardless of the relative merits of these arguments, there does seem to be a political role in the decision to send in troops. In response to pressure from UN headquarters, American troops were nominally placed under UN control. When the mission subsequently changed, with the prevalence of American troops in combat operations and within the UN command structure in Somalia, it was widely viewed as an American operation. The "mission creep," as it became known, led to the poorly informed decision to capture one of Somalia's leading warlords with disastrous results. Importantly, the widely viewed videos of the bodies of slain American soldiers subsequently being dragged behind vehicles in Mogadishu led to the American public's widespread loss of confidence in the mission, influencing then President Clinton to order the American contingent to head home. At every stage of the process, political realities and pressures influenced the use of military forces and this is unlikely to ever change. Suggesting that an important next step involves "harmonizing interagency roles" (102) and involving actors from government and NGOs does not seem particularly helpful given that the terms of the discourse have already been established.

Lastly, MARO appears to be remarkably unilateral in its orientation. In Part III, "Future Research Areas and Ways Forward," MARO's authors assert that "for a variety of reasons, the MARO Project's efforts have been initially US-centric" (102). 
This is problematic since it appears that, at least at this initial stage, the handbook perpetuates a unilateral approach to the idea of military intervention that is extremely troubling in this day and age. Regardless of the intention, American actions have all too often been perceived extremely negatively at home, within the affected region or nation, and internationally. Any single nation that engages in unilateral action, especially if it often uses military intervention as a strategy, runs the risk of having its motives discounted or assumed. Consider the recent case of the 2003 invasion of Iraq. Even though a small coalition of forces had been mustered in support of the action, many around the world condemned the action as American unilateralism at its worst. While American political and military leaders presented the action as a part of the "war on terror" and as a means of overthrowing a dictator and spreading democracy, many within the international community, within Iraq, and even within the United States saw it more as about a mission for oil and power than anything else. This perception certainly helped to mobilize popular opinion against the war in Iraq, and especially the American military presence there, and ultimately helped fuel the nationalism and religious factionalism that turned Iraq into a mass graveyard during the insurrection. That is not to suggest that multilateral actions are easy to organize and implement. On the contrary, they are difficult, highly politicized processes that require a great deal of consensus and much negotiation. Nevertheless, multilateral military interventions are inherently more legitimate as they do not automatically invoke the same kinds of negative reactions within the nation that is being invaded by troops and within the international community. In other words, the more nations that send troops to end atrocity crimes, the harder it is to portray the intervention as illegitimate. As Martha Finnemore reminds us, "To be legitimate in contemporary politics, humanitarian intervention must be multilateral." 15

\section{Notes}

1. International Rescue Committee conducted a number of mortality surveys between 2000 and 2007. See International Rescue Committee, accessed 5 October 2010, http://www.rescue.org/special-reports/congo-forgotten-crisis.

2. MONUC: United Nations Organization Mission in the Democratic Republic of the Congo, accessed 14 October 2010,

http://www.un.org/en/peacekeeping/missions/monuc/facts.shtml.

3. See, for example, Jeffrey Gettleman, "Mass Rapes in Congo Reveals U.N. Weakness," The New York Times 3 October 2010, http://www.nytimes.com/2010/10/04/world/africa/04congo.html (accessed 6 October 2010).

4. Gareth Evans and Mohamed Sahnoun, Co-chairs, The Responsibility to Protect: The Report of the International Commission on Intervention and State Sovereignty, (Ottawa, ON: International Development Research Centre, December 2001).

5. Madeleine K. Albright and William S. Cohen, Preventing Genocide: A Blueprint for U.S. Policymakers (Washington, DC: Genocide Prevention Task Force, 2008).

6. Sarah Sewall, Dwight Raymond, and Sally Chin, MARO: Mass Atrocity Response Operations; A Military Planning Handbook (Cambridge, MA: Harvard Kennedy School / Carr Centre for Human Rights Policy, 2010), 13. Subsequent references appear parenthetically in the text.

7. David H. Petraeus and James F. Amos, Counterinsurgency, FM 3-24 (Washington, DC: Combined Arms Center, 2006), http://usacac.army.mil/cac2/coin/repository/FM_3-24.pdf (accessed 6 October 2010).

8. See, for example, Andrew J. Bacevich, Washington Rules: America's Path to Permanent War (New York: Metropolitan Books, 2010). 
9. Ibid., 13.

10. Ibid., 16 .

11. See, for example, David A. Hamburg, Preventing Genocide: Practical Steps toward Early Detection and Effective Action (Boulder, CO: Paradigm Publishers, 2008).

12. Gareth Evans, The Responsibility to Protect: Ending Mass Atrocity Crimes Once and for All (Washington, DC: Brookings Institute, 2008).

13. Wesley K. Clark, Waging Modern War: Bosnia, Kosovo, and the Future of Combat (New York: Public Affairs, 2002).

14. L. M. Martin, "Somalia: Humanitarian Success and Political/Military Failure," Global Security, 1995, accessed 11 November 2010, http://www.globalsecurity.org/military/library/report/1995/MLM.htm.

15. Martha Finnemore, The Purpose of Intervention: Changing Beliefs about the Use of Force (Ithaca, NY: Cornell University Press, 2003), 78. 